\title{
THE INFLUENCE OF CALCIUM AND NITROGEN FERTILIZATION ON THE FREEZING AND SALINITY TOLERANCE OF TWO URBAN TREE SPECIES
}

\author{
By Glynn C. Percival' ${ }^{1}$ and S. Barnes ${ }^{2}$
}

\begin{abstract}
Two field trials were undertaken to determine the influence of fall fertilization using two commercially available, calcium-based fertilizers (calcium nitrate, calcium nitrate borate) and a high-nitrogen fertilizer ( $\mathrm{N}: \mathrm{P}: \mathrm{K}=24: 7: 7)$, at a range of concentrations, on the freezing and salinity tolerance of two urban tree species, evergreen oak (Quercus ilex) and holly (Ilex aquifolium). In both the 2001 and 2002 field trials, fertilization with calcium nitrate and calcium nitrate borate at a concentration of $40 \mathrm{~g} / \mathrm{m}^{2}\left(0.12 \mathrm{oz} / \mathrm{ft}^{2}\right)$ increased the freezing and salinity tolerance of both species as measured by leaf chlorophyll fluorescence, electrolyte leakage, and chlorophyll content. In addition, calcium fertilization at this concentration significantly increased total plant dry weight recorded at the cessation of the experiment. Application of both calcium fertilizers at concentrations of less than $40 \mathrm{~g} / \mathrm{m}^{2}$ provided no significant protectant properties. Applications of more than $40 \mathrm{~g} / \mathrm{m}^{2}$ proved phytotoxic to the two test species. Irrespective of concentration, applications of N:P:K (24:7:7) fertilizer did not enhance or increase susceptibility to freezing and salinity damage compared to nonfertilized controls. However, N:P:K (24:7:7) fertilization significantly increased leaf chlorophyll content and total plant dry weight. Results indicate that fall applications of calcium nitrate and calcium nitrate borate at $40 \mathrm{~g} / \mathrm{m}^{2}$ can increase the freezing and salinity tolerance of evergreen oak and holly.
\end{abstract}

Key Words. Evergreen oak; holly; chlorophyll fluorescence; electrolyte leakage; SPAD values; chlorophyll content; fertilizer.

Application of road de-icing salts in combination with direct freezing damage to urban trees following subzero temperatures during winter can result in significant tree mortalities (Dobson 1991; Percival and Fraser 2001). Likewise, late spring frosts can be devastating to newly emerged leaf tissue, resulting in reduced plant quality and often death (Cannel and Smith 1986; Cameron and Dixon 1997). Indeed, it has been estimated that freezing damage is indirectly and directly responsible for the deaths of more than 1 million urban trees annually on a global basis (Sakai and Larcher 1987). Protection against freezing and salt damage will become more important as climatic change may increase the unpredictability of weather patterns, resulting in progressively later frosts on an annual basis (Biggs 1996), and increased traffic volume and road network expansion may increase the quantity of salt used for de-icing operations (Percival and Fraser 2001).
Attempts to improve hardiness, through plant breeding, are limited by the nature of freezing and salt tolerance, which are quantitatively inherited traits controlled by many genes. Consequently, there is a demand for protectant compounds that are both inexpensive and can be applied at relatively short notice. It is now well recognized that applications of calcium (Ca) can reduce stress injury in plants by increasing cell wall strength ( $\mathrm{Ca}$ is a major nutrient responsible for cell wall rigidity), maintaining plasma membrane integrity and transport function (a primary site of tissue injury during stress), and inducing formation of new proteins with stress-protective characteristics (Palta 1996). Previous research has shown that applications of calcium sprays can improve winter hardiness of fruit trees and increase time spent in cold store of fruit and vegetables such as avocados, mangoes, cherries, and apples (Anderson and Campbell 1995; Raese 1996). Little investigation exists into whether applications of calcium can improve the freezing and salt tolerance of urban trees.

Objectives of this investigation were to (1) determine the effectiveness and feasibility of two commercially available Ca fertilizers (calcium nitrate and calcium nitrate borate) to improve the freezing and salt tolerance of two tree species commonly planted in urban environments; (2) determine the concentration conferring maximal resistance to freezing and salt damage; and (3) comparatively evaluate both $\mathrm{Ca}$ fertilizers against a conventionally used, high-nitrogen fertilizer (N:P:K= 24:7:7).

\section{METHODS \\ Plant Material and Experimental Design Cell grown, 3-year-old, $45 \mathrm{~cm}$ (18 in.) high stock of ever- green oak (Quercus ilex L.) and holly (Ilex aquifolium L.) were obtained from a commercial supplier on 13 September 2001 and stored outdoors on a free-draining gravel surface. To ensure uniformity of stock for experimental purpose, trees were graded, and only those confirming to the characteristics specified in Table 1 were used. The experi- mental design consisted of three randomized, complete block designs at the University of Reading, Shinfield Field Experimental Station, Reading, United Kingdom. Within each block were eighteen $3 \times 2 \mathrm{~m}(9.9 \times 6.6 \mathrm{ft})$ plots}


separated by rows of guard trees at $0.5 \mathrm{~m}(1.65 \mathrm{ft})$ spacings Within each plot, one of nine fertilizer treatments was used per species, along with a nonfertilized control:

- Ca nitrate $\left(\mathrm{Ca}\left(\mathrm{NO}_{3}\right)_{2}\right.$, trade name Tropicote ${ }^{\mathrm{TM}}$ (Yara UK Ltd, Immingham, N.E, Lincolnshire, UK), applied at 20, 40 , and $80 \mathrm{~g} / \mathrm{m}^{2}\left(0.07,1.4\right.$, and $\left.2.8 \mathrm{oz} / \mathrm{ft}^{2}\right)$

- Ca nitrate borate $\left(\mathrm{Ca}\left(\mathrm{NO}_{3}\right)_{2} \mathrm{H}_{3} \mathrm{BO}_{3}\right.$, trade name Nitrabor $^{\mathrm{TM}}$ (Yara UK Ltd, Immingham, N.E, Lincolnshire, UK), applied at 20, 40, and $80 \mathrm{~g} / \mathrm{m}^{2}$

- high-nitrogen fertilizer ( $\mathrm{N}: \mathrm{P}: \mathrm{K}=24: 7: 7$, trade name Bartlett BOOST, The Doggett Corporation, Lebanon, NJ) applied at 20,40 , and $80 \mathrm{~g} / \mathrm{m}^{2}$

Table 1. Physical characteristics of evergreen oak (Quercus ilex) and holly (Ilex aquifolium) after grading.

\begin{tabular}{lll}
\hline Attribute & Holly & Evergreen oak \\
\hline Height $(\mathrm{cm})$ & $46.3(2.20)^{*}$ & $45.3(2.11)$ \\
Girth $(\mathrm{cm})$ & $1.56(0.18)$ & $1.52(0.15)$ \\
Height:girth ratio $(\mathrm{cm} / \mathrm{cm})$ & $29.7(2.08)$ & $29.1(1.98)$ \\
Shoot and leaf dry weight $(\mathrm{g})$ & $4.80(0.39)$ & $4.71(0.38)$ \\
Root dry weight $(\mathrm{g})$ & $4.10(0.38)$ & $5.16(0.39)$ \\
Shoot:root ratio $(\mathrm{g} / \mathrm{g})$ & $1.17(0.10)$ & $0.91(0.08)$ \\
Root area $\left(\mathrm{cm}^{2}\right)$ & $35.36(3.02)$ & $40.17(3.26)$ \\
\hline
\end{tabular}

"Values are mean and standard errors for 10 trees.

Thirty evergreen oak and holly were used per fertilizer treatment (i.e., $2 \times 9 \times 10=180$ trees per block, 10 trees per plot [ 90 evergreen oak, 90 holly]; $3 \times 180=540$ trees total).

Fertilizers were applied uniformly to all plots by broadcast on the soil surface. All fertilizers were applied in the fall (4 October 2001) and trees planted by hand at $0.5 \mathrm{~m}(1.65$ $\mathrm{ft}$ ) spacings 1 week later. The soil was a sandy loam containing $4 \%$ to $6 \%$ organic matter and had a pH of 6.2. Available $\mathrm{P}, \mathrm{K}, \mathrm{Mg}, \mathrm{Na}$, and Ca were 52, 659.1, 175.2, 49.4, and 2,188 $\mathrm{mg} / \mathrm{L}$, respectively. Weeds were controlled chemically using glyphosate (Roundup, Green-Tech, Sweethills Park, Nun Monkton, York, UK) prior to planting and by hand throughout the experiment. No watering was required during the experimental period. Based on results of the 2001 trial, the experiment was repeated in 2002 on the same dates using only four of the nine treatments: $\mathrm{Ca}\left(\mathrm{NO}_{3}\right)_{2}, \mathrm{Ca}\left(\mathrm{NO}_{3}\right)_{2} \mathrm{H}_{3} \mathrm{BO}_{3}$, $\mathrm{N}: \mathrm{P}: \mathrm{K}(24: 7: 7)$ applied at $40 \mathrm{~g} / \mathrm{m}^{2}\left(1.4 \mathrm{oz} / \mathrm{ft}^{2}\right)$, and a nonfertilized control.

\section{Freezing Treatments}

At months 1, 2, 4, and 8 post-fertilization, two fully expanded, nonsenescing leaves per tree, 15 trees per fertilizer treatment ( 5 trees per block) were excised at the base of the petiole using a razor blade and placed abaxial surface down, in a Petri dish on moist Watman's filter paper and sealed with a thin polythene film permeable to air but not water, then placed in darkness in a Merck environmental freezing chamber, where the temperature was reduced by $2^{\circ} \mathrm{C}$ $\left(3.6^{\circ} \mathrm{F}\right)$ per $\mathrm{h}$ from $10^{\circ} \mathrm{C}\left(50^{\circ} \mathrm{F}\right)$ to $-8^{\circ} \mathrm{C}\left(18^{\circ} \mathrm{F}\right)$. This temperature was maintained for $4 \mathrm{~h}$, after which the temperature was raised by $2^{\circ} \mathrm{C}$ per $\mathrm{h}$ to $10^{\circ} \mathrm{C}$, a cooling regime representative of a naturally occurring severe frost (Sakai and Larcher 1987). All leaf material was prepared within $2 \mathrm{~h}$ of collection from the field.

\section{Salt Treatments}

At months 1, 2, 4, and 8 post-fertilization two fully expanded, nonsenescing leaves per tree, 15 trees per fertilizer treatment ( 5 trees per block) were excised at the base of the petiole using a razor blade. Upon arrival at the laboratory $(<2 \mathrm{~h}$ after collection), leaves were immersed in an $8 \%$ salt $(\mathrm{NaCl})$ solution for $2 \mathrm{~min}$. After salt immersion, leaves were placed, abaxial surface down, in a Petri dish on moist Watman's filter paper sealed with a thin polythene film permeable to air but not water. Following all treatments, leaf samples were placed in a Merck environmental growth chamber in darkness at $22^{\circ} \mathrm{C}\left(72^{\circ} \mathrm{F}\right)$ for $72 \mathrm{~h}$, a time after which detrimental effects on chlorophyll fluorescence values could be detected (Greaves and Wilson 1987).

Because of the potential influence of leaf removal on total plant dry weights measured at the cessation of the experiment, leaves were taken only from the same 15 trees at months 1, 2, 4, and 8 . The remaining 15 undamaged trees were used to obtain dry weight measurements recorded at month 8 .

\section{Physiological Tests}

Because leaf chlorophyll fluorescence and SPAD measurements are noninvasive and nondestructive, following each measurement the same evergreen oak and holly leaves were used to obtain electrolyte leakage values. All physiological measurements taken at months 1, 2, 4, and 8 were obtained on leaf material present on the plant at the initiation of the experiment (existing leaves). In addition, physiological measurements at month 8 only were also taken from newly formed spring leaf tissue (i.e., new leaves not present at the time of fertilizer application).

\section{Chlorophyll Fluorescence}

Immediately after the freezing treatment and $72 \mathrm{~h}$ postsalinity treatments, leaves were adapted to darkness for 30 min by attaching light exclusion clips to the leaf surface. Chlorophyll fluorescence was measured using a HandyPEA portable fluorescence spectrometer (Hansatech Instruments Ltd., King's Lynn, UK). Measurements were recorded up to 1 $\mathrm{s}$ with a data acquisition rate of $10 \mu \mathrm{s}$ for the first $2 \mathrm{~ms}$ and of $1 \mathrm{~ms}$ thereafter. The fluorescence responses were induced by a red (peak at $650 \mathrm{~nm}$ ) light of $1500 \mu \mathrm{mol} \mathrm{m} / \mathrm{s}$ photosynthetically active radiation (PAR) intensity provided by an array of six light-emitting diodes. The ratio of variable 
$(\mathrm{Fv}=\mathrm{Fm}-\mathrm{Fo})$ to maximal (Fm) fluorescence (i.e., Fv/Fm, where Fo = minimal fluorescence) of dark adapted leaves and Fo values alone were used to quantify the detrimental effects of freezing on leaf tissue. An increase in Fo is characteristic of destruction of photosystem II reaction centers (Yamada et al. 1996). Fv/Fm is considered a quantitative measure of the maximal or potential photochemical efficiency or optimal quantum yield of photosystem II (Willits and Peet 2001). Likewise, Fv/Fm values are the most popular index used as a measure of plant vitality and early diagnostic of stress (Meinander et al. 1996).

\section{Chlorophyll Measurements}

A Minolta chlorophyll meter SPAD-502 was used. Chlorophyll was measured at the midpoint of the leaf next to the main leaf vein. Calibration was obtained by measurement of absorbance at 663 and $645 \mathrm{~nm}$ in a spectrophotometer (PU8800 Pye Unicam) after extraction with 80\% v/v aqueous acetone (regression equation $=5.80+0.057 x ; r^{2}$ $\operatorname{adj}=0.82, P=<0.01$ ) (Lichtenthaler and Wellburn 1983).

\section{Leaf Electrolyte Leakage}

Quantitative damage to leaf tissue (freezing treatment only) was assessed by measuring electrolyte leakage of entire leaves post-freezing. Excised leaves were placed in $50 \mathrm{~mL}$ (1.5 oz) Universal bottles containing $30 \mathrm{~mL}(0.9 \mathrm{oz})$ distilled water and gently shaken by hand. Samples were stored at $22^{\circ} \mathrm{C}\left(72^{\circ} \mathrm{F}\right)$ for $24 \mathrm{~h}$ in darkness prior to conductivity measurements taken with a Jenway conductivity probe and M4070 meter (BDH, Leicestershire, Loughborough, UK). Total solute leakage was obtained by autoclaving for $1 \mathrm{~h}$ at $121^{\circ} \mathrm{C}\left(249^{\circ} \mathrm{F}\right)$ and $0.103 \mathrm{MPa}$. Results are presented as percentage of solute leakage after 24 h (McKay 1992).

\section{Dry Weights and Leaf Area}

At the conclusion of the experiment, trees were destructively harvested. Leaf, shoot, and root dry weight were recorded after oven drying at $85^{\circ} \mathrm{C}\left(184^{\circ} \mathrm{F}\right)$ for $48 \mathrm{~h}$. Root areas were quantified using a Delta-T area meter. Stem diameter was quantified using Manta blue precision calipers (Langsele, Haglof AB, Sweden) at one-third of the height of the stem and girth calculated using the equation $C=\pi D$ where $C=$ circumference (girth), $\pi=3.14$, and $D=$ diameter. Height was recorded by measuring the distance from the tip of the leading apical shoot to the soil surface.

\section{Data Analysis}

Because measurements at months $1,2,4$, and 8 were obtained from the same plant, the relationship $\left(\beta_{1}\right)$ between physiological measurements over time following freezing and salinity treatments was quantified using repeated measures analysis (regression). Significant effects, salient interactions, and whether $\beta_{1}$ was significantly different from nonfertilized controls were determined by both two- and one-way analyses of variance (ANOVA) after checks for normality and equal variance distributions (Anderson-Darling test) were conducted. Differences between treatment means were separated by the least significance difference (LSD) at the 95\% confidence level $(P<0.05)$ using the Genstat for Windows ${ }^{\circledR}$ program. The 2001 and 2002 data sets were not different when compared using a t-test; therefore, values presented represent data for 2001 trials only.

\section{RESULTS AND DISCUSSION}

A significant effect $(P<0.05)$ of species was recorded (Table 2). Following freezing, Fo regression values as a measure of damage to photosystem II reaction centers were 10\% to $20 \%$ higher than following salt damage in both test species. Likewise, Fv/Fm regression values as a measure of photochemical efficiency and SPAD regression values as a measure of leaf chlorophyll content were $10 \%$ to $20 \%$ lower following freezing compared to salt damage for both species (Tables 3 and $4 *$ ). This finding indicates that a freezing temperature of $-8^{\circ} \mathrm{C}\left(18^{\circ} \mathrm{F}\right)$ is more detrimental to leaf tissue than salt stress at a concentration of $8 \%$. Similar results were obtained by Percival and Fraser (2001) when evaluating a range of Crataegus genotypes for their salinity and freezing tolerance. Higher Fo and leaf electrolyte leakage (freezing only) regression values (10\% to $30 \%$ ) and lower $\mathrm{Fv} / \mathrm{Fm}$ and SPAD regression values of $10 \%$ to $30 \%$ following both salt and freezing stress in holly compared to evergreen oak (Tables 3 and 4) indicate that when selecting species for planting in areas where salinity and freezing temperatures are prevalent, evergreen oak should be chosen to help avoid replacement costs. Previous research investigating the freezing tolerance of a range of trees commonly planted in UK urban environments supports the conclusion that evergreen oak is a more freezing-tolerant species compared to holly (Percival and Henderson 2003).

*Tables 3 through 7 appear on pp. 16-20.

Table 2. Statistical analysis of variance for examination of salient effects and interactions on leaf chlorophyll fluorescence (Fo, Fv/Fm), chlorophyll concentration (SPAD), and electrolyte leakage.

\begin{tabular}{lccccc}
\hline Factor & df & Fo & Fv/Fm & SPAD & Electrolyte leakage \\
\hline One-way interactions & & & & & \\
SPECIES (SP) & 1 & $* *$ & $* *$ & $* *$ & - \\
FERTILIZER (F) & 3 & $* *$ & $* *$ & $* *$ & $*$ \\
CONC (C) & 8 & $* *$ & $* *$ & $* *$ & $* *$ \\
Two-way interactions & & & & & \\
SP*F*C & 24 & $* *$ & $* *$ & $*$ & - \\
\hline
\end{tabular}

* = significant at $P<0.05,{ }^{*}=$ significant at $P<0.01$. 
Measurements of Fo and leaf electrolyte leakage were $50 \%$ higher, while measurements of Fv/Fm and SPAD values were $50 \%$ lower in newly formed spring leaf tissue (new leaves; Tables 5 and 6) sampled at month 8 compared to leaf tissue sampled at month 8 that was present at the time of fertilizer application (existing leaves; Tables 3 and 4), irrespective of form of stress applied and tree species (Tables 4 through 7). Previous research has shown that newly formed leaves produced in spring are highly susceptible to a range of environmental stresses such as freezing, heat, and salinity compared to older, more mature leaf tissue due to the new leaves' inability to acclimate (Cannel and Smith 1986; Cameron and Dixon 1997).

A significant effect of fertilizer and concentration applied was recorded (Table 1). Such a response is reflected in the results where, compared to nonfertilized controls, significantly lower $(P<0.05)$ Fo and electrolyte leakage regression values (20\% to $40 \%$ ), coupled with significantly higher $(P<0.05) \mathrm{Fv} / \mathrm{Fm}$ and SPAD regression values (30\% to $40 \%$ ), indicate that the freezing and salinity tolerance of evergreen oak and holly can be increased by fall application of $\mathrm{Ca}\left(\mathrm{NO}_{3}\right)_{2}$ and $\mathrm{Ca}\left(\mathrm{NO}_{3}\right)_{2} \mathrm{H}_{3} \mathrm{BO}_{3}$ at a concentration of 40 $\mathrm{g} / \mathrm{m}^{2}\left(1.4 \mathrm{oz} / \mathrm{ft}^{2}\right)$ (Tables 3 and 4 ). Results also show that increases in freezing and salinity tolerance were apparent in newly formed spring leaf tissue measured at month 8 (Tables 5 and 6). This finding indicates that fall fertilization with $\mathrm{Ca}\left(\mathrm{NO}_{3}\right)_{2}$ and $\mathrm{Ca}\left(\mathrm{NO}_{3}\right)_{2} \mathrm{H}_{3} \mathrm{BO}_{3}$ at $40 \mathrm{~g} / \mathrm{m}^{2}$ can improve not only the freezing and salinity tolerance of existing leaf material through the winter months but also that of newly formed leaf tissue in spring.

Improvements in freezing and salinity hardiness of plants following calcium fertilization have been shown to be achieved via alterations to a number of plant physiological processes. The structural stability of cell walls and plasma membranes results from calcium links between phosphate and plasma lipids. Consequently, applications of calcium can physically increase the strength of the plant cell wall (Legge et al. 1982).

Calcium has also been implicated in controlling enzyme activity, important in improving freezing resistance. For example, cold temperatures increase levels of a calciumdependent NAD kinase, which, in turn, is responsible for activating enzymes that cause the production of proteins necessary to alter the transcription of genes specific to cold acclimation. The progress of freezing injury can be also be halted by bathing or washing freeze-thaw-injured tissue in a calcium-based solution. (Monroy et al. 1993; Berbezy et al. 1996). Electrolyte leakage is widely used to measure freezing damage via alterations in membrane structural integrity (McKay 1992; Percival and Galloway 1999). Reduced electrolyte leakage values in trees fertilized with $\mathrm{Ca}\left(\mathrm{NO}_{3}\right)_{2}$ and $\mathrm{Ca}\left(\mathrm{NO}_{3}\right)_{2} \mathrm{H}_{3} \mathrm{BO}_{3}$ at a concentration of $40 \mathrm{~g} / \mathrm{m}^{2}\left(1.4 \mathrm{oz} / \mathrm{ft}^{2}\right)$ following freezing damage indicate increased membrane structural stability and cell wall strength caused by calcium fertilization in both test species. Importantly, improvements in freezing and salinity tolerance were recorded by month 1 (Tables 3 and 4), indicating calcium fertilization works rapidly to induce stress resistance in both evergreen oak and holly. Increased tolerance to salinity and freezing stress as a result of calcium fertilization at $40 \mathrm{~g} / \mathrm{m}^{2}$ may also have contributed toward the significantly increased $(P<0.05)$ plant dry weights recorded at the cessation of the experiment (Table 7 ).

Although Fo and electrolyte leakage regression values were generally lower in both test species supplemented with $\mathrm{Ca}\left(\mathrm{NO}_{3}\right)_{2}$ and $\mathrm{Ca}\left(\mathrm{NO}_{3}\right)_{2} \mathrm{H}_{3} \mathrm{BO}_{3}$ at a concentration of $20 \mathrm{~g} / \mathrm{m}^{2}$ $\left(0.7 \mathrm{oz} / \mathrm{ft}^{2}\right)$ and $\mathrm{Fv} / \mathrm{Fm}, \mathrm{SPAD}$ regression values and plant dry weights were generally higher compared to controls; in few instances were they significantly so (Tables 3 through 7 ). This finding indicates that applications of calcium-based fertilizers at $20 \mathrm{~g} / \mathrm{m}^{2}$ conferred no significant protectant properties in the two test species. Likewise, applications of both calcium fertilizers at a concentration of $80 \mathrm{~g} / \mathrm{m}^{2}(2.8$ $\left.\mathrm{oz} / \mathrm{ft}^{2}\right)$ had no significant effect on freezing and salinity tolerance or plant dry weights (Tables 3 through 7). Symptoms of fertilizer burn were observed in both tree species at this concentration (marginal necrosis of the leaf peripheral edges) indicating phytotoxicity of both calcium fertilizers at $80 \mathrm{~g} / \mathrm{m}^{2}$, which may account for this result.

Irrespective of species, there was no marked difference in freezing and salinity tolerance and dry weight values between trees treated with $\mathrm{Ca}\left(\mathrm{NO}_{3}\right)_{2}$ and $\mathrm{Ca}\left(\mathrm{NO}_{3}\right)_{2} \mathrm{H}_{3} \mathrm{BO}_{3}$ at a concentration of $40 \mathrm{~g} / \mathrm{m}^{2}$ (Tables 3 through 7). Both fertilizers are commercially available at a cost of US $\$ 288$ (£160) for $\mathrm{Ca}\left(\mathrm{NO}_{3}\right)_{2}$ and $\$ \mathrm{US} 304$ (£169) for $\mathrm{Ca}\left(\mathrm{NO}_{3}\right)_{2} \mathrm{H}_{3} \mathrm{BO}_{3}$ per metric ton at farm gate prices. Such knowledge may prove of importance to those involved in urban tree care, when the cost-benefit ratio involved with calcium fertilization needs to be considered.

Nitrogen fertilization has been shown to reduce winter hardiness in apple (Way 1953; Edgerton 1957), pear (Raese 1997), and peach (Proebstring 1961). Contrary to these findings, work elsewhere suggests nitrogen fertilization can enhance winter hardiness in Picea ruben (Dehaynes et al. 1998) and Juniperus chinensis (Pellet and White 1969), while Smiley and Shirazi (2000) suggest nitrogen fertilization has no significant effect on winter hardiness in Forsythia, maple (Acer spp.), Leyland cypress ( $\times$ Cupressocyparis leylandii), and oak (Quercus spp.).

Irrespective of species, chlorophyll fluorescence (Fo, Fv/ Fm) and electrolyte leakage regression values did not significantly differ from controls following freezing and salinity stresses following fall fertilization with a highnitrogen (N:P:K 24:7:7) fertilizer (Tables 3-7). This result indicates that fertilization of evergreen oak and holly with a $\mathrm{N}: \mathrm{P}: \mathrm{K}(24: 7: 7)$ fertilizer did not enhance or increase susceptibility to freezing and salinity damage. However, 
significantly higher SPAD regression values as a measure of leaf chlorophyll concentration and overall plant dry weights were recorded (Tables 3 through 7).

Leaf nitrogen status has been shown to be highly correlated with leaf chlorophyll concentration (i.e., "greenness") and yield in a range of plants (Evans 1983; Seemann et al. 1987; Hoel 1998). Higher leaf nitrogen content as a result of N:P:K (24:7:7) fertilization in both evergreen oak and holly may account for the improved leaf color and total plant dry weights recorded. Consequently, results of this investigation indicate that although application of a N:P:K (24:7:7) fertilizer induced no significant freezing and salinity protectant properties in evergreen oak and holly, leaf color and overall growth were significantly $(P<0.05)$ better in both species compared to nonfertilized controls. Similar results have been obtained elsewhere using pear (Pyrus spp.) as a test species (Raese 1997).

In conclusion, previous investigations have shown that calcium fertilization can improve the salinity and freezing tolerance of apple and pear trees cultivated under orchard conditions (Raese 1996); trees used in urban landscapes such as hornbeam (Carpinus spp.), and white poplar (Populus alba) (Percival et al. 1999); fruit and vegetables such as beans, potatoes, avocados, mangoes, cherries; and various grass species (Akhavankharazian et al. 1991; Anderson and Campbell 1995; Palta 1996). The present study offers further evidence in this respect.

Acknowledgments. The authors are grateful for funding from the TREE Fund (John Z. Duling grant program).

\section{LITERATURE CITED}

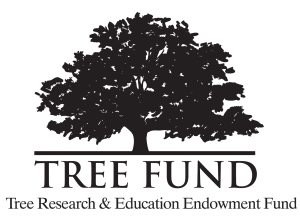

Akhavankharazian, M., W.F. Campbell, J.J. Jurinak, and L.M. Dudley. 1991. Calcium amelioration of $\mathrm{NaCl}$ effects on plant growth, chlorophyll, and ion concentration in Phaseolus vulgaris. Arid Soil Res. Rehabil. 5:9-19.

Anderson, J.L., and W.F. Campbell. 1995. Calcium transport and ATPase activity in microsomal vesicle fraction from 'Montmorency' sour cherry fruit. Acta Hortic. 398:47-57.

Berbezy, P., L. Legendre, and A. Maujean. 1996. Purification and characterisation of alpha-amylase from vine shoot inter-nodes. Plant Physiol. Biochem. 34(3):353-361.

Biggs, M.P. 1996. Low temperature acclimation and associated physiological changes in species of Rhododendron. Ph.D. thesis. University of Strathclyde, in association with SAC Auchincruive.

Cameron, R.W.F., and G.R. Dixon. 1997. Air temperature, humidity and rooting volume affecting freezing injury to Rhododendron and other perennials. J. Hortic. Sci. Biotechnol. 72(4):553-562.

Cannel, M.G.R., and R.I. Smith. 1986. Climatic warming, spring budburst and frost damage on trees. J. Appl. Ecol. 23:177-191.
Dehaynes, D.H., M.A. Ingle, and C.E. White. 1998. Nitrogen fertilization enhances cold tolerance of red spruce seedlings. Can J. For. Res. 19:1037-1043.

Dobson, M.C. 1991. De-icing salt damage to trees and shrubs. For. Commiss. Bull. 101.

Edgerton, I. J. 1957. Effects of nitrogen fertilization on cold hardiness of apple trees. Proc. Am. Soc. Hortic. Sci. 70:40-45.

Evans, J.T. 1983. Nitrogen and photosynthesis in the flag leaf of wheat. Plant Physiol. 72:297-302.

Greaves, J.A., and J.M. Wilson. 1987. Chlorophyll fluorescence analysis-An aid to plant breeders. Biologist 34(4):209-214.

Hoel, B.O. 1998. Use of a handheld chlorophyll meter in winter wheat: Evaluation of different measuring positions on the leaf. Acta Agric. Scand. 48:222-228.

Legge, R.L., E. Thompson, J.E. Baker, and M. Lieberman. 1982. The effect of calcium on the fluidity and phase properties of microsomal membranes isolated from postclimacteric Golden Delicious apples. Plant Cell Physiol. 23:161-169.

Lichtenthaler, H.K., and A.R. Wellburn. 1983. Determinations of total carotenoids and chlorophylls $a$ and $b$ of leaf extracts in different solvents. Biochem. Soc. Transcr. 11:591-593.

McKay, H. 1992. Electrolyte leakage from fine roots of conifer seedlings: A rapid index of plant vitality following cold storage. Can. J. For. Res. 22:1371-1377.

Meinander, O., S. Somersalo, T. Holopainen, and R.J. Strasser. 1996. Scots pine after exposure to elevated ozone and carbon dioxide probed by reflectance spectra and chlorophyll $a$ fluorescence transients. J. Plant Physiol. 148:229-236.

Monroy, A.F., F. Sarhan, and R.S. Dhindsa. 1993. Coldinduced changes in freezing tolerance, protein phosphorylation, and gene expression. Plant Physiol. 102:1227-1235.

Palta, J.P. 1996. Role of calcium in plant responses to stresses: Linking basic research to the solution of practical problems. HortScience 31(1):51-57.

Pellet, N.E., and D.B. White. 1969. Effects of soil nitrogen and soil moisture levels on cold acclimation of containergrown Juniperus chinensis 'Hetsi'. J. Am. Soc. Hortic. Sci. 94:457-459.

Percival, G.C., and G.A. Fraser. 2001. Measurement of the salinity and freezing tolerance of Crataegus genotypes using chlorophyll fluorescence. J. Arboric. 27(5):233245.

Percival, G.C., and A. Galloway. 1999. The potential of chlorophyll fluorescence measurements to detect salt and waterlogging stress in urban trees. Acta Hortic. 496:253-259. 
Percival, G.C., and A. Henderson. 2003. An assessment of the freezing tolerance of urban trees using chlorophyll fluorescence. J. Hortic. Sci. Biotechnol. 78(2):254-260.

Percival, G.C., C. Boyle, and L. Baird. 1999. The influence of calcium supplementation on the freezing tolerance of woody plants. J. Arboric. 25(6):285-291.

Proebstring, E.L. 1961. Cold hardiness of Elberta peach fruit buds as influenced by nitrogen level and cover crop. Proc. Am. Soc. Hortic Sci. 77:97-106.

Raese, J.T. 1996. Winter hardiness increased with calcium treatments. Good Fruit Grower 47:4, 41-48.

- 1997. Cold tolerance, yield and fruit quality of d'Anjou pears influenced by nitrogen fertilizer rates and time of application. J. Plant Nutr. 20:1007-1025.

Sakai, A., and W. Larcher. 1987. Frost Survival of PlantsResponses and Adaptations to Freezing Stress. SpringerVerlag, London, UK.

Seemann, J.R., T.D. Sharkey, J. Wang, and C.B. Osmond. 1987. Environmental effects on photosynthesis, nitrogen use efficiency and metabolite pools in leaves of sun and shade plants. Plant Physiol. 84:796-802.

Smiley, E.T., and A.M. Shirazi. 2000. Fall fertilization and winter hardiness, pp 93-103. In Proceedings from an International Conference on Tree and Shrub Fertilization, May 17-18, 2000, Fairlawn, Ohio. International Society of Arboriculture, Champaign, IL.

Way, R.D. 1953. The effects of some cultural practices and of size of crop on the subsequent winter hardiness of some apple trees. Proc. Am. Soc. Hortic Sci. 63:163-166.

Willits, D.H., and M.M. Peet. 2001. Using chlorophyll fluorescence to model leaf photosynthesis in greenhouse pepper and tomato. Acta Hortic. 507:311-315.

Yamada, M., T. Hidaka, and H. Fukamachi. 1996. Heat tolerance in leaves of tropical fruit crops as measured by chlorophyll fluorescence. Sci. Hortic. 67:39-48.

\author{
The University of Reading \\ 2 Early Gate \\ Whiteknights \\ Reading, RG6 6AU \\ United Kingdom
${ }^{2}$ School of Biology
University of Nottingham
University Park
Nottingham, NG7 2RD
United Kingdom

${ }^{1 *}$ R.A. Bartlett Tree Research Laboratory, Europe

*Corresponding author.
Résumé. Deux champs d'essais ont été utilisés pour déterminer l'influence de la fertilisation d'automne au moyen de deux engrais commerciaux contenant une base en calcium (nitrate de calcium et borate-nitrate de calcium) et d'un engrais à teneur élevée en azote $(\mathrm{N}: \mathrm{P}: \mathrm{K}=24: 7: 7)$, et ce à différentes concentrations par rapport à la tolérance au gel et à la salinité pour deux espèces urbaines d'arbres, soient le chêne houx (Quercus ilex) et le houx commun (Ilex aquifolium). Dans les deux champs d'essais en 2001 et 2002, la fertilisation à une concentration de $40 \mathrm{~g}$ au $\mathrm{m}^{2}$ avec le nitrate de calcium et le borate-nitrate de calcium a permis d'accroître la tolérance au gel et à la salinité chez les deux espèces, tolérance observée par des mesures de fluorescence de la chlorophylle, de perte d'électrolytes et de contenu chlorophyllien. De plus, la fertilisation en calcium à cette concentration a permis d'accroître significativement la masse sèche totale de la plante qui a été enregistrée à la fin de l'expérience. Lapplication des deux engrais en calcium à des concentrations inférieures à $40 \mathrm{~g}$ au m² n'a donné aucun effet significatif sur les propriétés de protection. Quant aux applications à des taux supérieurs à $40 \mathrm{~g}$ au $\mathrm{m}^{2}$, ces dernières se sont avérés être phytotoxiques pour les deux espèces d'arbres. En dépit de la concentration, les applications d'engrais azoté n'ont pas permis d'améliorer, non plus qu'elles ont diminué, la tolérance au gel et à la salinité, et ce en comparaison avec les arbres-témoin. Cependant, la fertilisation azotée a significativement accrû le contenu en chlorophylle foliaire et la masse sèche totale de la plante. En conclusions, ces résultats indiquent que les applications automnales de nitrate de calcium et de borate-nitrate de calcium à des taux de $40 \mathrm{~g}$ au $\mathrm{m}^{2}$ peut permettre d'accroître la tolérance au gel et à la salinité chez le chêne houx et le houx commun.

Zusammenfassung. Es wurden 2 Feldversuche angeordnet, um den Einfluss von Herbstdüngung mit 2 kommerziell erhältlichen Kalziumdüngern (Kalziumnitrat, Kalziumnitratborat) und einem Stickstoffdünger (N:P:K= 24:7:7) auf die Spannbreite der Frost- und Salztoleranz bei zwei Baumarten, Immergrüne Eiche und Stechpalme, zu bestimmen. In beiden Feldversuchen von 2001 und 2002 vergrößerte die Düngung mit Kalziumnitrat und Kalziumnitratborat bei einer Konzentration von $40 \mathrm{~g} / \mathrm{m}^{2}$ die Frostund Salzresistenz, die in Blattchlorophyll-Fluoreszenz, Elektrolytaustritt und Chlorophyllgehalt gemessen wurde. Außerdem vergrößerte die Kalziumdüngung bei dieser Konzentration das totale Trockengewicht, welches am Ende des Experiments gemessen wurde. Die Applikation beider Kalziumdünger mit einer Konzentration von weniger als $40 \mathrm{~g} / \mathrm{m}^{2}$ lieferte keinen bedeutsamen Schutz. Die Applikation von über 40g/ $\mathrm{m}^{2}$ erwies sich für beide Arten als phytotoxisch. Unabhängig von der Konzentration verbesserte weder noch verstärkte die Stickstoffdüngung die Anfälligkeit gegenüber Frost oder Salzschäden im Vergleich zu den ungedüngten Kontrollen. Trotzdem verbesserte die Stickstoffdüngung den Blattchlorophyllgehalt und das totale Pflanzentrockengewicht. In der Zusammenfassung zeigen die Ergebnisse, dass die Herbstapplikationen von Kalziumdüngern bei $40 \mathrm{~g} / \mathrm{m}^{2}$ die Frostund Salztoleranz bei Immergrüner Eiche und Stechpalme verbessern können. 


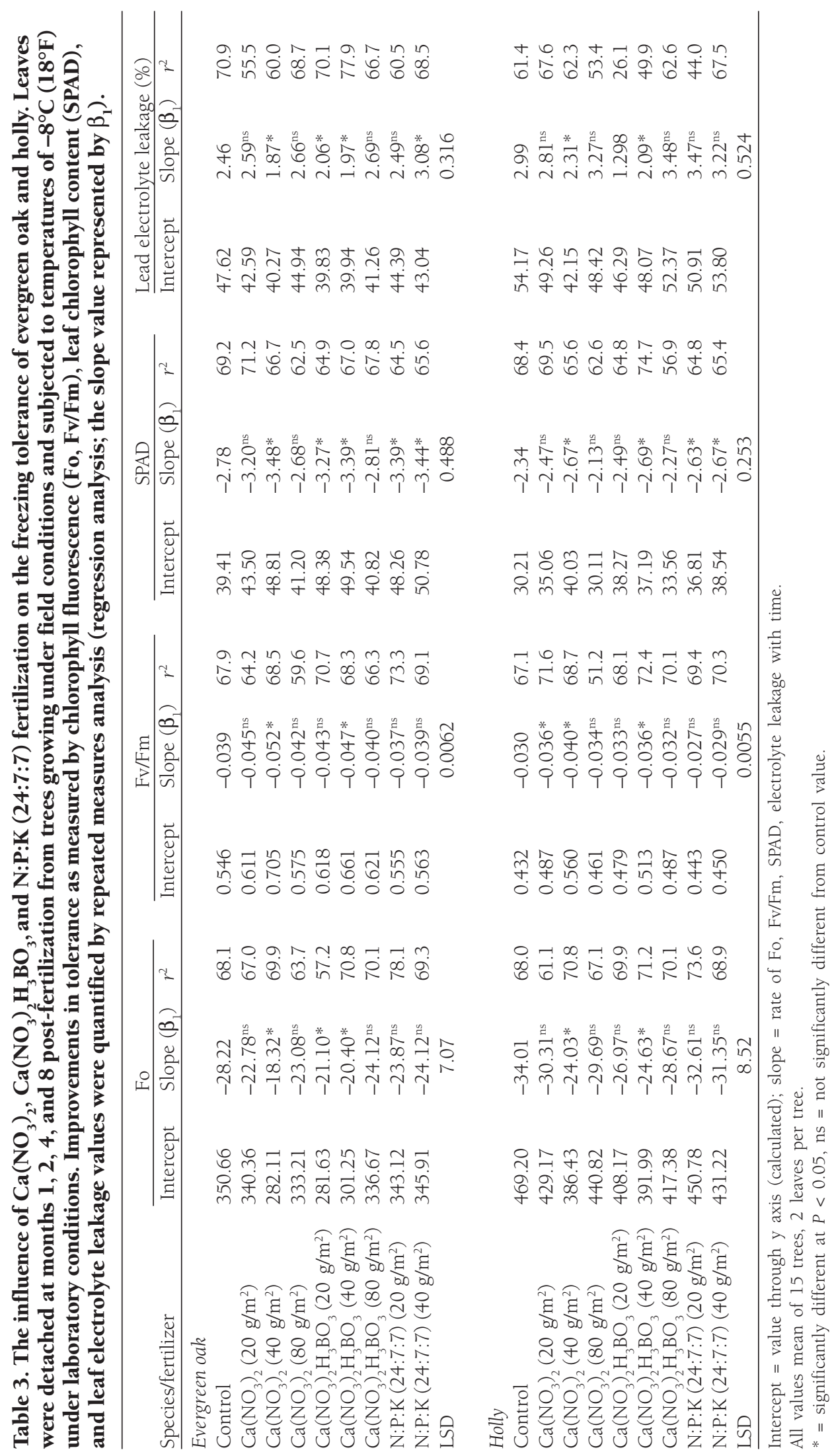


Table 4. The influence of $\mathrm{Ca}\left(\mathrm{NO}_{3}\right)_{2}, \mathrm{Ca}\left(\mathrm{NO}_{3}\right)_{2} \mathrm{H}_{3} \mathrm{BO}_{3}$, and N:P:K (24:7:7) fertilization on the salinity tolerance of evergreen oak and holly. Leaves were detached at months $1,2,4$, and 8 post-fertilization from trees growing under field conditions and subjected to $8 \%$ salt $(\mathrm{NaCl})$ exposure under laboratory conditions. Improvements in tolerance as measured by chlorophyll fluorescence (Fo, Fv/Fm) and leaf chlorophyll content (SPAD) values were quantified by repeated measures analysis (regression analysis; the slope value represented by $\beta_{1}$ ).

\begin{tabular}{|c|c|c|c|c|c|c|c|c|c|}
\hline \multirow[b]{2}{*}{ Species/fertilizer } & \multicolumn{3}{|c|}{ Fo } & \multicolumn{3}{|c|}{$\mathrm{Fv} / \mathrm{Fm}$} & \multicolumn{3}{|c|}{ SPAD } \\
\hline & Intercept & Slope $\left(\beta_{1}\right)$ & $r^{2}$ & Intercept & Slope $\left(\beta_{1}\right)$ & $r^{2}$ & Intercept & Slope $\left(\beta_{1}\right)$ & $r^{2}$ \\
\hline \multicolumn{10}{|l|}{ Evergreen oak } \\
\hline Control & 351.89 & -23.96 & 69.2 & 0.610 & -0.043 & 70.2 & 44.09 & -3.19 & 68.6 \\
\hline $\mathrm{Ca}\left(\mathrm{NO}_{3}\right)_{2}\left(20 \mathrm{~g} / \mathrm{m}^{2}\right)$ & 331.91 & $-22.51^{\mathrm{ns}}$ & 67.5 & 0.709 & $-0.050^{\mathrm{ns}}$ & 64.0 & 48.27 & $-3.51^{\mathrm{ns}}$ & 67.2 \\
\hline $\mathrm{Ca}\left(\mathrm{NO}_{3}\right)_{2}\left(40 \mathrm{~g} / \mathrm{m}^{2}\right)$ & 279.53 & $-17.35^{*}$ & 68.4 & 0.791 & $-0.058 *$ & 68.6 & 54.23 & $-3.80 *$ & 70.3 \\
\hline $\mathrm{Ca}\left(\mathrm{NO}_{3}\right)_{2}\left(80 \mathrm{~g} / \mathrm{m}^{2}\right)$ & 314.39 & $-20.52^{\mathrm{ns}}$ & 67.0 & 0.631 & $-0.048^{\mathrm{ns}}$ & 57.8 & 45.46 & $-2.99^{\mathrm{ns}}$ & 63.6 \\
\hline $\mathrm{Ca}\left(\mathrm{NO}_{3}\right)_{2} \mathrm{H}_{3} \mathrm{BO}_{3}\left(2 \mathrm{~g} / \mathrm{m}^{2}\right)$ & 300.78 & $-19.33 *$ & 70.5 & 0.689 & $-0.048^{\mathrm{ns}}$ & 69.0 & 53.55 & $-3.60 *$ & 64.7 \\
\hline $\mathrm{Ca}\left(\mathrm{NO}_{3}\right)_{2} \mathrm{H}_{3} \mathrm{BO}_{3}\left(40 \mathrm{~g} / \mathrm{m}^{2}\right)$ & 281.43 & $-17.22 *$ & 66.3 & 0.729 & $-0.051 *$ & 68.5 & 51.48 & $-3.66^{*}$ & 70.5 \\
\hline $\mathrm{Ca}\left(\mathrm{NO}_{3}\right)_{2} \mathrm{H}_{3} \mathrm{BO}_{3}\left(80 \mathrm{~g} / \mathrm{m}^{2}\right)$ & 310.68 & $-21.70^{\mathrm{ns}}$ & 70.2 & 0.685 & $-0.049^{\mathrm{ns}}$ & 70.2 & 47.75 & $-3.13^{\mathrm{ns}}$ & 67.4 \\
\hline $\mathrm{N}: \mathrm{P}: \mathrm{K}(24: 7: 7)\left(20 \mathrm{~g} / \mathrm{m}^{2}\right)$ & 329.48 & $-21.44^{\mathrm{ns}}$ & 43.5 & 0.619 & $-0.042^{\mathrm{ns}}$ & 69.7 & 55.63 & $-3.69 *$ & 65.2 \\
\hline $\mathrm{N}: \mathrm{P}: \mathrm{K}(24: 7: 7)\left(40 \mathrm{~g} / \mathrm{m}^{2}\right)$ & 315.35 & $-20.89^{\text {ns }}$ & 68.9 & 0.634 & $-0.043^{\mathrm{ns}}$ & 69.0 & 57.74 & $-3.72 *$ & 66.4 \\
\hline LSD & & 4.11 & & & 0.0072 & & & 0.409 & \\
\hline \multicolumn{10}{|l|}{ Holly } \\
\hline Control & 439.62 & -30.88 & 74.6 & 0.493 & -0.034 & 69.9 & 34.58 & -2.30 & 67.9 \\
\hline $\mathrm{Ca}\left(\mathrm{NO}_{3}\right)_{2}\left(20 \mathrm{~g} / \mathrm{m}^{2}\right)$ & 397.21 & $-26.91^{\mathrm{ns}}$ & 61.0 & 0.539 & $-0.038^{\mathrm{ns}}$ & 68.9 & 37.12 & $-2.70^{\mathrm{ns}}$ & 69.7 \\
\hline $\mathrm{Ca}\left(\mathrm{NO}_{3}\right)_{2}\left(40 \mathrm{~g} / \mathrm{m}^{2}\right)$ & 361.26 & $-23.20^{*}$ & 67.5 & 0.619 & $-0.045^{*}$ & 68.6 & 42.86 & $-2.92 *$ & 65.3 \\
\hline $\mathrm{Ca}\left(\mathrm{NO}_{3}\right)_{2}\left(80 \mathrm{~g} / \mathrm{m}^{2}\right)$ & 404.43 & $-27.66^{\mathrm{ns}}$ & 67.0 & 0.520 & $-0.040^{\mathrm{ns}}$ & 51.8 & 34.66 & $-2.21^{\mathrm{ns}}$ & 63.4 \\
\hline $\mathrm{Ca}\left(\mathrm{NO}_{3}\right)_{2} \mathrm{H}_{3} \mathrm{BO}_{3}\left(2 \mathrm{~g} / \mathrm{m}^{2}\right)$ & 382.81 & $-25.96^{*}$ & 68.7 & 0.544 & $-0.037^{\mathrm{ns}}$ & 69.0 & 41.17 & $-2.81^{*}$ & 64.4 \\
\hline $\mathrm{Ca}\left(\mathrm{NO}_{3}\right)_{2} \mathrm{H}_{3} \mathrm{BO}_{3}\left(40 \mathrm{~g} / \mathrm{m}^{2}\right)$ & 369.14 & $-24.67^{*}$ & 70.0 & 0.567 & $-0.041 *$ & 68.4 & 41.56 & $-2.83 *$ & 67.1 \\
\hline $\mathrm{Ca}\left(\mathrm{NO}_{3}\right)_{2} \mathrm{H}_{3} \mathrm{BO}_{3}\left(80 \mathrm{~g} / \mathrm{m}^{2}\right)$ & 392.58 & $-26.97^{\mathrm{ns}}$ & 70.3 & 0.531 & $-0.038^{\mathrm{ns}}$ & 69.9 & 36.94 & $-2.46^{\mathrm{ns}}$ & 67.8 \\
\hline $\mathrm{N}: \mathrm{P}: \mathrm{K}(24: 7: 7)\left(20 \mathrm{~g} / \mathrm{m}^{2}\right)$ & 422.90 & $-28.89^{\text {ns }}$ & 74.9 & 0.497 & $-0.031^{\mathrm{ns}}$ & 69.5 & 44.17 & $-2.95^{*}$ & 65.1 \\
\hline $\mathrm{N}: \mathrm{P}: \mathrm{K}(24: 7: 7)\left(40 \mathrm{~g} / \mathrm{m}^{2}\right)$ & 414.73 & $-27.80^{\mathrm{ns}}$ & 69.1 & 0.491 & $-0.033^{\mathrm{ns}}$ & 67.0 & 43.41 & $-2.88^{*}$ & 65.3 \\
\hline LSD & & 4.70 & & & 0.0068 & & & 0.447 & \\
\hline
\end{tabular}

Intercept $=$ value through y axis (calculated); slope $=$ rate of Fo, Fv/Fm, SPAD, electrolyte leakage with time.

All values mean of 15 trees, 2 leaves per tree.

* = significantly different at $P<0.05, \mathrm{~ns}=$ not significantly different from control value. 
Table 5. The influence of $\mathrm{Ca}\left(\mathrm{NO}_{3}\right)_{2}, \mathrm{Ca}\left(\mathrm{NO}_{3}\right)_{2} \mathrm{H}_{3} \mathrm{BO}_{3}$, and $\mathrm{N}: \mathrm{P}: \mathrm{K}(24: 7: 7)$ fertilization on the freezing tolerance of spring foliage of evergreen oak and holly. Newly emerged leaves were detached at month 8 post-fertilization from trees growing under field conditions and subjected to $-8^{\circ} \mathrm{C}\left(18^{\circ} \mathrm{F}\right)$ under laboratory conditions. Improvements in tolerance were measured by chlorophyll fluorescence (Fo, Fv/Fm), leaf chlorophyll content (SPAD), and leaf electrolyte leakage.

\begin{tabular}{|c|c|c|c|c|}
\hline Species/fertilizer & Fo & $\mathrm{Fv} / \mathrm{Fm}$ & SPAD & $\begin{array}{l}\text { Leaf electrolyte } \\
\text { leakage (\%) }\end{array}$ \\
\hline \multicolumn{5}{|l|}{ Evergreen oak } \\
\hline Control & $159.9(24.33)$ & $0.261(0.028)$ & $18.5(4.07)$ & $70.7(14.66)$ \\
\hline $\mathrm{Ca}\left(\mathrm{NO}_{3}\right)_{2}\left(20 \mathrm{~g} / \mathrm{m}^{2}\right)$ & $150.3^{\text {ns }}(31.42)$ & $0.281^{\mathrm{ns}}(0.063)$ & $20.4^{\mathrm{ns}}(6.11)$ & $66.4^{\mathrm{ns}}(16.10)$ \\
\hline $\mathrm{Ca}\left(\mathrm{NO}_{3}\right)_{2}\left(40 \mathrm{~g} / \mathrm{m}^{2}\right)$ & $121.3 *(17.68)$ & $0.325 *(0.041)$ & $24.3 *(5.32)$ & $56.9 *(15.40)$ \\
\hline $\mathrm{Ca}\left(\mathrm{NO}_{3}\right)_{2}\left(80 \mathrm{~g} / \mathrm{m}^{2}\right)$ & $146.5^{\text {ns }}(19.60)$ & $0.244^{\mathrm{ns}}(0.031)$ & $18.9^{\text {ns }}(3.87)$ & $66.8^{\mathrm{ns}}(17.21)$ \\
\hline $\mathrm{Ca}\left(\mathrm{NO}_{3}\right)_{2} \mathrm{H}_{3} \mathrm{BO}_{3}\left(20 \mathrm{~g} / \mathrm{m}^{2}\right)$ & $131.9 *(26.55)$ & $0.295 *(0.037)$ & $23.6 *(4.46)$ & $57.0 *(13.28)$ \\
\hline $\mathrm{Ca}\left(\mathrm{NO}_{3}\right)_{2} \mathrm{H}_{3} \mathrm{BO}_{3}\left(40 \mathrm{~g} / \mathrm{m}^{2}\right)$ & $124.6 *(30.13)$ & $0.312 *(0.040)$ & $23.3 *(4.17)$ & $62.3^{\text {ns }}(16.75)$ \\
\hline $\mathrm{Ca}\left(\mathrm{NO}_{3}\right)_{2} \mathrm{H}_{3} \mathrm{BO}_{3}\left(80 \mathrm{~g} / \mathrm{m}^{2}\right)$ & $137.5^{\text {ns }}(19.75)$ & $0.284^{\mathrm{ns}}(0.018)$ & $19.9^{\text {ns }}(6.25)$ & $67.7^{\mathrm{ns}}(13.26)$ \\
\hline $\mathrm{N}: \mathrm{P}: \mathrm{K}(24: 7: 7)\left(20 \mathrm{~g} / \mathrm{m}^{2}\right)$ & $141.2^{\mathrm{ns}}(18.80)$ & $0.259^{\mathrm{ns}}(0.020)$ & $24.1 *(8.08)$ & $65.8^{\text {ns }}(13.58)$ \\
\hline $\mathrm{N}: \mathrm{P}: \mathrm{K}(24: 7: 7)\left(40 \mathrm{~g} / \mathrm{m}^{2}\right)$ & $146.5^{\text {ns }}(22.62)$ & $0.264^{\mathrm{ns}}(0.038)$ & $24.3 *(7.13)$ & $72.9^{\text {ns }}(16.50)$ \\
\hline LSD & 27.54 & 0.0311 & 4.66 & 13.11 \\
\hline \multicolumn{5}{|l|}{ Holly } \\
\hline Control & $207.7(32.20)$ & $0.204(0.019)$ & $14.3(3.14)$ & $79.0(15.21)$ \\
\hline $\mathrm{Ca}\left(\mathrm{NO}_{3}\right)_{2}\left(20 \mathrm{~g} / \mathrm{m}^{2}\right)$ & $195.1^{\mathrm{ns}}(38.54)$ & $0.219^{\text {ns }}(0.022)$ & $15.7^{\mathrm{ns}}(3.70)$ & $72.1^{\mathrm{ns}}(17.49)$ \\
\hline $\mathrm{Ca}\left(\mathrm{NO}_{3}\right)_{2}\left(40 \mathrm{~g} / \mathrm{m}^{2}\right)$ & $157.5^{*}(31.49)$ & $0.253 *(0.034)$ & $18.7 *(4.13)$ & $64.8^{*}(14.11)$ \\
\hline $\mathrm{Ca}\left(\mathrm{NO}_{3}\right)_{2}\left(80 \mathrm{~g} / \mathrm{m}^{2}\right)$ & $190.4^{\mathrm{ns}}(40.36)$ & $0.189^{\text {ns }}(0.015)$ & $14.6^{\text {ns }}(4.39)$ & $78.2^{\mathrm{ns}}(20.79)$ \\
\hline $\mathrm{Ca}\left(\mathrm{NO}_{3}\right)_{2} \mathrm{H}_{3} \mathrm{BO}_{3}\left(20 \mathrm{~g} / \mathrm{m}^{2}\right)$ & $171.3 *(22.66)$ & $0.230^{\mathrm{ns}}(0.027)$ & $18.2 *(5.66)$ & $59.3 *(11.96)$ \\
\hline $\mathrm{Ca}\left(\mathrm{NO}_{3}\right)_{2} \mathrm{H}_{3} \mathrm{BO}_{3}\left(40 \mathrm{~g} / \mathrm{m}^{2}\right)$ & $161.7 *(30.21)$ & $0.243 *(0.034)$ & $17.9 *(6.13)$ & $65.0^{\text {ns }}(13.57)$ \\
\hline $\mathrm{Ca}\left(\mathrm{NO}_{3}\right)_{2} \mathrm{H}_{3} \mathrm{BO}_{3}\left(80 \mathrm{~g} / \mathrm{m}^{2}\right)$ & $178.8^{\mathrm{ns}}(26.39)$ & $0.221^{\mathrm{ns}}(0.021)$ & $14.7^{\mathrm{ns}}(5.71)$ & $82.1^{\text {ns }}(18.60)$ \\
\hline $\mathrm{N}: \mathrm{P}: \mathrm{K}(24: 7: 7)\left(20 \mathrm{~g} / \mathrm{m}^{2}\right)$ & $183.5^{\text {ns }}(28.48)$ & $0.202^{\mathrm{ns}}(0.022)$ & $18.6 *(7.60)$ & $83.4^{\mathrm{ns}}(16.23)$ \\
\hline $\mathrm{N}: \mathrm{P}: \mathrm{K}(24: 7: 7)\left(40 \mathrm{~g} / \mathrm{m}^{2}\right)$ & $190.2^{\mathrm{ns}}(24.30)$ & $0.206^{\mathrm{ns}}(0.022)$ & $18.7 *(5.28)$ & $80.4^{\mathrm{ns}}(15.63)$ \\
\hline LSD & 34.76 & 0.0288 & 3.16 & 11.67 \\
\hline
\end{tabular}

All values mean of 15 trees, 2 leaves per tree.

* = significantly different at $P<0.05$, ns $=$ not significantly different from control value.

Values in parentheses represent the standard error of the mean. 
Table 6. The influence of $\mathrm{Ca}\left(\mathrm{NO}_{3}\right)_{2}, \mathrm{Ca}\left(\mathrm{NO}_{3}\right)_{2} \mathrm{H}_{3} \mathrm{BO}_{3}$, and N:P:K (24:7:7) fertilization on the salt tolerance of spring foliage of evergreen oak and holly. Newly emerged leaves were detached at month 8 post-fertilization from trees growing under field conditions and subjected to $8 \%$ salt $(\mathrm{NaCl})$ exposure under laboratory conditions. Improvements in tolerance were measured by chlorophyll fluorescence (Fo, Fv/Fm) and leaf chlorophyll content (SPAD).

\begin{tabular}{|c|c|c|c|}
\hline Species/fertilizer & Fo & $\mathrm{Fv} / \mathrm{Fm}$ & SPAD \\
\hline \multicolumn{4}{|l|}{ Evergreen oak } \\
\hline Control & $148.7(32.13)$ & $0.236(0.050)$ & $17.8(4.66)$ \\
\hline $\mathrm{Ca}\left(\mathrm{NO}_{3}\right)_{2}\left(20 \mathrm{~g} / \mathrm{m}^{2}\right)$ & $139.7^{\text {ns }}(28.24)$ & $0.253^{\text {ns }}(0.038)$ & $18.5^{\mathrm{ns}}(3.98)$ \\
\hline $\mathrm{Ca}\left(\mathrm{NO}_{3}\right)_{2}\left(40 \mathrm{~g} / \mathrm{m}^{2}\right)$ & $112.8 *(30.11)$ & $0.292 *(0.045)$ & $22.1^{\text {ns }}(4.44)$ \\
\hline $\mathrm{Ca}\left(\mathrm{NO}_{3}\right)_{2}\left(80 \mathrm{~g} / \mathrm{m}^{2}\right)$ & $136.3^{\text {ns }}(25.67)$ & $0.219^{\text {ns }}(0.038)$ & $17.4^{\text {ns }}(3.88)$ \\
\hline $\mathrm{Ca}\left(\mathrm{NO}_{3}\right)_{2} \mathrm{H}_{3} \mathrm{BO}_{3}\left(2 \mathrm{~g} / \mathrm{m}^{2}\right)$ & $122.7 *(30.17)$ & $0.265 *(0.042)$ & $21.4^{\mathrm{ns}}(5.21)$ \\
\hline $\mathrm{Ca}\left(\mathrm{NO}_{2}\right)_{2} \mathrm{H}_{3} \mathrm{BO}{ }_{2}\left(40 \mathrm{~g} / \mathrm{m}^{2}\right)$ & $115.9 *(31.98)$ & $0.280 *(0.040)$ & $21.3^{\mathrm{ns}}(5.07)$ \\
\hline $\mathrm{Ca}\left(\mathrm{NO}_{3}\right)_{2} \mathrm{H}_{3} \mathrm{BO}_{3}^{3}\left(80 \mathrm{~g} / \mathrm{m}^{2}\right)$ & $127.9 *(27.60)$ & $0.256^{\mathrm{ns}}(0.058)$ & $18.3^{\text {ns }}(3.45)$ \\
\hline $\mathrm{N}: \mathrm{P}: \mathrm{K}(24: 7: 7)\left(20 \mathrm{~g} / \mathrm{m}^{2}\right)$ & $131.5^{\text {ns }}(39.04)$ & $0.234^{\mathrm{ns}}(0.059)$ & $21.7^{\mathrm{ns}}(4.28)$ \\
\hline $\mathrm{N}: \mathrm{P}: \mathrm{K}(24: 7: 7)\left(40 \mathrm{~g} / \mathrm{m}^{2}\right)$ & $136.2^{\text {ns }}(39.41)$ & $0.238^{\mathrm{ns}}(0.043)$ & $22.9^{\text {ns }}(6.65)$ \\
\hline LSD & 20.61 & 0.0277 & 5.03 \\
\hline \multicolumn{4}{|l|}{ Holly } \\
\hline Control & $193.1(36.78)$ & $0.184(0.039)$ & $13.7(4.90)$ \\
\hline $\mathrm{Ca}\left(\mathrm{NO}_{2}\right)_{2}\left(20 \mathrm{~g} / \mathrm{m}^{2}\right)$ & $181.4^{\text {ns }}(39.44)$ & $0.197^{\text {ns }}(0.041)$ & $14.2^{\mathrm{ns}}(5.09)$ \\
\hline $\mathrm{Ca}\left(\mathrm{NO}_{3}\right)_{2}\left(40 \mathrm{~g} / \mathrm{m}^{2}\right)$ & $146.5 *(38.90)$ & $0.227 *(0.044)$ & $17.0 *(5.38)$ \\
\hline $\mathrm{Ca}\left(\mathrm{NO}_{3}\right)_{2}\left(80 \mathrm{~g} / \mathrm{m}^{2}\right)$ & $177.0^{\text {ns }}(37.88)$ & $0.171^{\mathrm{ns}}(0.039)$ & $13.4^{\mathrm{ns}}(4.00)$ \\
\hline $\mathrm{Ca}\left(\mathrm{NO}_{3}\right)_{2} \mathrm{H}_{3} \mathrm{BO}_{3}\left(2 \mathrm{~g} / \mathrm{m}^{2}\right)$ & $159.2 *(30.25)$ & $0.207^{\mathrm{ns}}(0.051)$ & $16.5^{\mathrm{ns}}(3.72)$ \\
\hline $\mathrm{Ca}\left(\mathrm{NO}_{2}\right)_{2} \mathrm{H}_{3} \mathrm{BO}{ }_{2}\left(40 \mathrm{~g} / \mathrm{m}^{2}\right)$ & $150.4 *(34.56)$ & $0.219 *(0.045)$ & $16.4^{\mathrm{ns}}(4.21)$ \\
\hline $\mathrm{Ca}\left(\mathrm{NO}_{3}\right)_{2} \mathrm{H}_{3} \mathrm{BO}_{3}^{3}\left(80 \mathrm{~g} / \mathrm{m}^{2}\right)$ & $166.2^{\text {ns }}(32.30)$ & $0.199^{\text {ns }}(0.048)$ & $13.5^{\mathrm{ns}}(6.28)$ \\
\hline $\mathrm{N}: \mathrm{P}: \mathrm{K}(24: 7: 7)\left(20 \mathrm{~g} / \mathrm{m}^{2}\right)$ & $170.6^{\text {ns }}(36.74)$ & $0.182^{\text {ns }}(0.037)$ & $16.8^{\mathrm{ns}}(5.13)$ \\
\hline $\mathrm{N}: \mathrm{P}: \mathrm{K}(24: 7: 7)\left(40 \mathrm{~g} / \mathrm{m}^{2}\right)$ & $176.9^{\text {ns }}(40.29)$ & $0.185^{\mathrm{ns}}(0.040)$ & $17.0 *(2.89)$ \\
\hline LSD & 30.66 & 0.0329 & 3.22 \\
\hline
\end{tabular}

All values mean of 15 trees, 2 leaves per tree.

* = significantly different at $P<0.05$, ns $=$ not significantly different from control value.

Values in parentheses represent the standard error of the mean. 


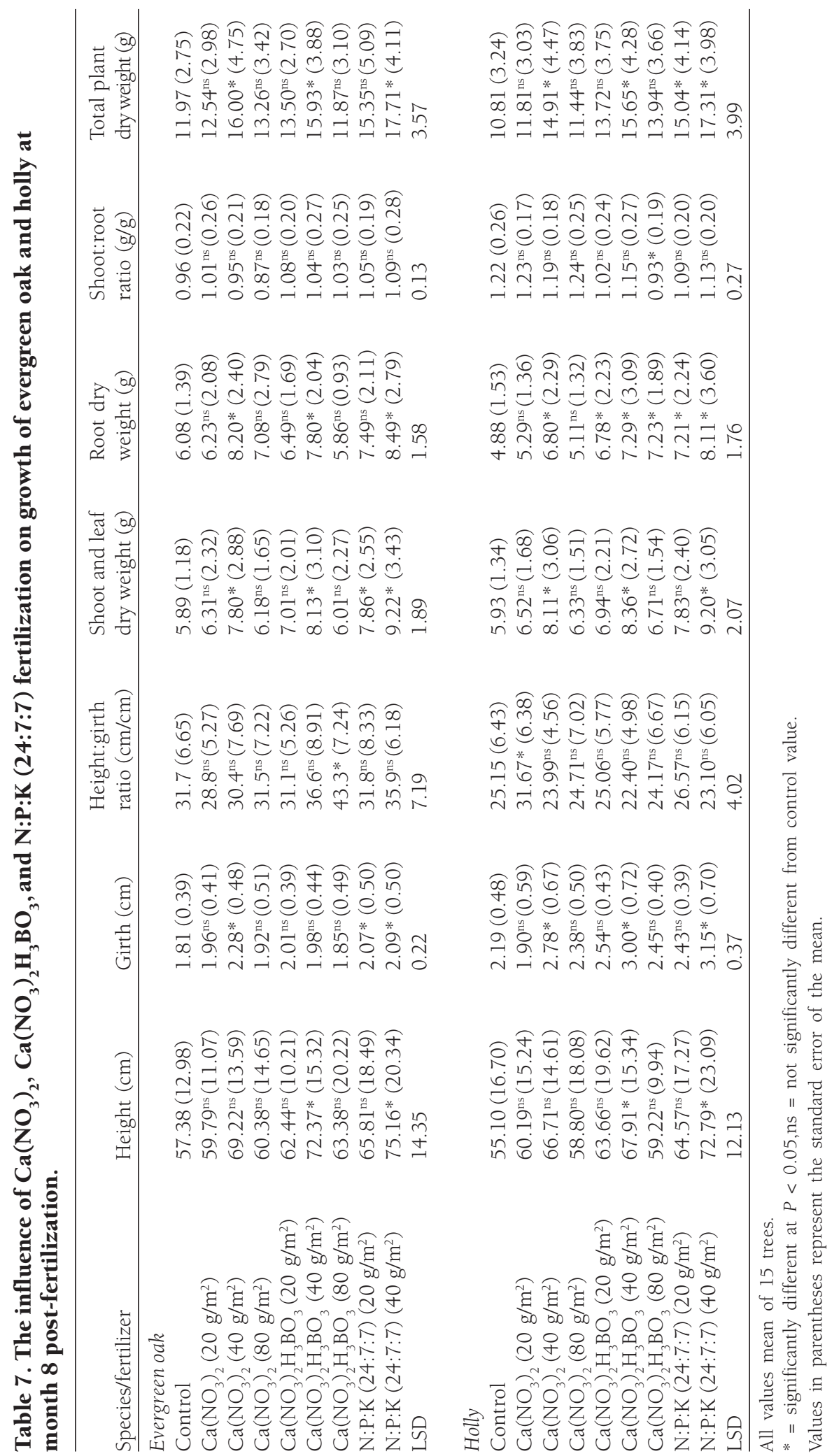

